\title{
GAYA SELINGKUNG DI UNS PRESS DAN KODE ETIK PENYUNTINGAN SEBAGAI PENOPANG EKSISTENSI PENULIS INDONESIA
}

\author{
DESI RIYANTIKA \\ Pendidikan Bahasa Indonesia, Universitas Sebelas Maret Surakarta \\ J1. Ir. Sutami No. 36A, Jebres, Kota Surakarta, Jawa Tengah 57126 \\ Email: riyantikadesi@gmail.com
}

\begin{abstract}
Abstrak
Penulisan ini bertujuan untuk mengetahui gaya selingkung di UNS Press dan kode etik penyuntingan sebagai penopang eksistensi penulis Indonesia. Penulisan ini menggunakan metode deskriptif. Objek dalam penulisan ini adalah kegiatan yang dilakukan selama magang di UNS Press mulai tanggal 21 Januari 2019-1 Maret 2019. Berdasarkan penulisan, diperoleh hasil bahwa: (1) UNS Press memiliki gaya selingkung sendiri yang terdiri dari delapan bagian, (2) alur penerimaan naskah di UNS Press terdapat sebelas langkah menerbitkan naskah dimulai dari penerimaan naskah hingga penerbitan naskah menjadi buku, (3) kode etik penyuntingan naskah terdiri dari enam poin yang menjadi pedoman bagi penyunting dalam menyunting naskah, dan (4) kepekaan bahasa berhubungan dengan kegiatan menyunting naskah meliputi kepekaan terhadap ejaan bahasa Indonesia, tata bahasa Indonesia, dan kamus.
\end{abstract}

Kata Kunci: gaya selingkung, UNS Press, kode etik penyuntingan

\begin{abstract}
This writing aims to find out the surrounding style of the UNS Press and the editing code of ethics as the support of the existence of Indonesian writers. This writing uses descriptive methods. The object in this writing is an activity carried out during an internship at the UNS Press starting on January 21, 2019-1 March 2019. Based on the writing, the results show that: (1) the UNS Press has its own style book which consists of eight parts, (2) the reception flow the manuscript in the UNS Press has eleven steps to publish the manuscript starting from the receipt of the manuscript to the publication of the manuscript into a book, (3) the script editing code of ethics consists of six points
\end{abstract}


that guide the editor in editing the script, and (4) language sensitivity related to editing the script includes sensitivity to Indonesian spelling, Indonesian grammar, and dictionaries.

Keywords: style book, UNS Press, editing code of ethics

\section{PENDAHULUAN}

Menulis menurut MC Crimmon merupakan kegiatan menggali pikiran dan perasaan mengenai subyek, memilih hal-hal yang akan ditulis, dan menentukan cara menuliskannya sehingga pembaca dapat memahaminya dengan mudah dan jelas (Saddhono \& Slamet, 2012:151). Menulis adalah keterampilan untuk berkomunikasi secara tidak langsung dan merupakan jenis keterampilan produktif dan ekspresif (Cahyaningrum, Andayani, dan Saddhono, 2018:44). Kegiatan menulis erat kaitannya dengan kegiatan penyuntingan. Penyuntingan adalah proses, cara, perbuatan menyunting atau sunting-menyunting (KBBI, 2009:1106). Menyunting adalah kegiatan mengolah dan menyiapkan naskah menjadi naskah yang siap dicetak dengan memperhatikan segi sistematika penyajian, isi, dan bahasa. Pada segi bahasa meliputi ejaan, diksi, struktur kalimat, dan gaya selingkung penulis. Orang yang melakukan pekerjaan menyunting naskah disebut dengan editor atau penyunting. Seorang penyunting naskah harus memenuhi syarat penyuntingan yang meliputi penguasaan ejaan bahasa Indonesia, tata bahasa Indonesia, ketelitian dan kesabaran, kemampuan menulis, keluwesan, penguasaan salah satu bidang keilmuwan, pengetahuan yang luas, kode etik penyuntingan, dan kepekaan bahasa.

Seorang penyunting harus memahami gaya selingkung penerbit, kode etik penyuntingan, dan kepekaan bahasa. Memahami kode etik penyuntingan naskah berarti penyunting harus tahu mana yang boleh dan tidak boleh dilakukan dalam penyuntingan naskah. Jika penyunting tidak memahami kode etik penyuntingan naskah menyebabkan terjadinya kemungkinan ia melakukan salah satu langkah atau salah sunting. Memiliki kepekaan bahasa penting dimiliki oleh penyunting. Hal ini karena penyunting berhubungan dengan ejaan, tata bahasa, dan kamus. Penyunting harus memiliki kemampuan membedakan kalimat mana yang kasar dan halus dan harus tau kapan 
kalimat atau kata tersebut digunakan atau dihindari. Oleh karena itu, seorang penyunting dituntut untuk memiliki kepekaan bahasa.

Seorang penyunting harus memahami kode etik penyuntingan naskah. Hal ini perlu diperhatikan agar menjadi rambu-rambu sebelum menyunting naskah. Menurut Eneste (2014:23), ada enam butir kode etik penyuntingan naskah yang perlu diperhatikan bagi penyunting naskah, antara lain: (1) penyunting wajib mencari informasi mengenai penulis naskah sebelum memulai menyunting naskah, (2) penyunting naskah bukanlah penulis naskah, (3) penyunting naskah wajib merahasiakan informasi yang terdapat dalam naskah yang disunting, (4) penyunting naskah wajib mengonsultasikan hal-hal yang mungkin akan diubah dalam naskah, (5) penyunting naskah tidak boleh menghilangkan naskah yang akan, sedang, atau telah disunting, dan (6) penyunting naskah wajib menghormati gaya penulis naskah.

Gaya selingkung adalah pedoman tata cara atau pedoman yang khas yang diterapkan sebuah penerbit untuk menampilkan terbitannya. Gaya selingkung ini menjadi pedoman, ciri khas dan pembeda antara penerbit satu dengan yang lain. Pedoman ini kemudian menjadi rujukan bagi editor, penyunting, dan penulis. Setiap penerbit memiliki gaya selingkung masing-masing sebagai tata tertib yang khas yang dijadikan pedoman dan kaidah kebahasaan serta menjadi pembeda dengan penerbit lain. Begitu pula dengan gaya selingkung setiap orang juga berbeda dengan yang lain, termasuk dalam menyajikan karya tulisan ilmiah (Irawati, 2016:284). Setiap karya tulis ilmiah termasuk artikel ilmiah memiliki gaya selingkung masing-masing sebagai tata tertib yang khas yang menjadi pembeda antara jurnal ilmiah satu dengan jurnal ilmiah lain. Pemilihan kata atau diksi pada dasarnya adalah hasil dari upaya memilih kata tertentu untuk dipakai dalam membuat kalimat, alinea, atau wacana (Yahya, Andayani, dan Saddhono:53). Pemilihan diksi dalam penulisan sangat penting untuk mengungkapkan maksud peneliti. Kesalahan diksi sering disebut sebagai kesalahan berbahasa (Mulyadi, 2017:6). Kesalahan berbahasa dalam proses pemerolehan dan pembelajaran merupakan proses yang mempengaruhi pembelajaran bahasa (Ariningsih, Sumarwati, Saddhono, 2012: 40).

UPT Penerbitan dan Percetakan Universitas Sebelas Maret atau yang lebih dikenal dengan nama UNS Press adalah salah satu unit penunjang Universitas Sebelas Maret yang berfungsi melaksanakan tugas penerbitan dan percetakan. UNS Press 
didirikan bertujuan untuk menerbitkan buku, jurnal, majalah, dan produk penerbitan lainnya. UNS Press menerbitkan karya ilmiah, terutama buku, dengan pengarang yang bisa berasal dari UNS sendiri dan dari luar UNS, baik dari perguruan tinggi maupun dari luar perguruan tinggi. Produk yang bertalian dengan pendidikan, hasil simposium atau seminar, dan hasil penelitian. UNS Press berkomitmen untuk memosisikan diri sebagai penerbit mandiri, profesional, standar ketat, kualitas teruji, dan biaya yang relatif murah. UNS Press berdiri pada tanggal 14 Agustus 1989 dengan SK Rektor No. 54/PT.40.D/89 tentang pembentukan Unit Pelaksana Teknis Penerbitan dan Percetakan Universitas Sebelas Maret. Tugas Utama UNS Press adalah melakukan kegiatan di bidang penerbitan dan pencetakan yang bersifat teknis, baik dengan buku maupun nonbuku. (https://uns.ac.id/id/fasilitas-kampus/upt-uns-press)

Tujuan memilih praktik di tempat magang UNS Press dapat digunakan untuk mengasah keterampilan mahasiswa dalam menerapkan ilmu yang didapatkan. Pembelajaran yang bersifat aplikatif didapatkan ketika magang. Adapun penilaian yang akan diberikan mencakup beberapa aspek sebagai berikut: (1) kedisiplinan, (2) kreativitas, (3) kerja sama tim, (4) produktivitas, (5) kualitas kerja, dan (6) nilai akhir/akumulatif.

\section{METODE PENELITIAN}

Metode yang digunakan dalam penulisan ini ialah menggunakan metode penulisan deskriptif. Menurut Best (dalam Sukardi, 2009: 157) menjelaskan metode deskriptif merupakan metode penulisan yang berusaha menggambarkan dan menginterpretasikan objek sesuai dengan apa adanya. Arikunto (2010:3) menegaskan bahwa metode diskriptif yaitu penulisan yang dimaksudkan untuk menyelidiki keadaan, kondisi, dan hal-hal lain. Ratna (2012:53) menegaskan bahwa penulisan deskriptif analitik dilakukan dengan cara mendeskripsikan fakta-fakta yang kemudian disusul dengan analisis. Metode ini digunakan untuk mengetahui gaya selingkung di UNS Press dan kode etik penyuntingan sebagai penopang eksistensi penulis Indonesia. Objek dalam penulisan ini adalah kegiatan yang dilakukan selama magang di UNS Press mulai tanggal 21 Januari 2019-1 Maret 2019 


\section{HASIL DAN PEMBAHASAN}

Pelaksanaan kegiatan magang penyuntingan di UNS Press tahun 2019 dilaksanakan pada tanggal 21 Januari 2019-1 Maret 2019. Kegiatan magang disana lebih berfokus pada bagian menyunting naskah dalam bentuk softfile. Kegiatan menyunting di UNS Press terdiri dari kegiatan mengolah dan menyiapkan naskah menjadi naskah yang siap dicetak dengan memperhatikan segi sistematika penyajian, isi, dan bahasa. Setelah selesai disunting, naskah akan masuk proses desain grafis untuk mendesain cover buku kemudian masuk pada proses pencetakan naskah.

Pada kegiatan penyuntingan naskah terdiri atas kegiatan menyunting ejaan bahasa Indonesia, tata bahasa Indonesia, ketelitian dan kesabaran, kemampuan menulis, keluwesan, penguasaan salah satu bidang keilmuwan, pengetahuan yang luas, kode etik penyuntingan, dan kepekaan bahasa. Penyuntingan ejaan bahasa diantaranya pemakaian huruf kapital dan miring, penulisan kata berupa kata depan, pemakaian tanda baca berupa titik, koma, titik dua, dan pisah, serta penulisan unsur serapan. Selain itu juga menyunting penggunaan kata baku, pemilihan diksi, salah ketik, kalimat efektif, penyusunan daftar pustaka, pemilihan diksi, akronim, penulisan nama gelar, dan sebagainya. Buku Pedoman Umum Ejaan Bahasa Indonesia digunakan sebagai acuan dan pedoman dalam menyunting naskah selama kegiatan magang. Ditinjau dari segi bahasa perlu diperhatikan tentang kalimat-kalimat, keterpaduan antarparagraf, dan kebenaran informasi pada naskah.

\section{Gaya Selingkung}

Gaya selingkung adalah pedoman tata cara atau pedoman yang khas yang diterapkan sebuah penerbit untuk menampilkan terbitannya. Gaya selingkung ini menjadi pedoman, ciri khas dan pembeda antara penerbit satu dengan yang lain. Sama halnya dengan penerbit lain, UNS Press juga memiliki gaya selingkung sendiri yang membedakan antara UNS Press dengan penerbit lain. Berikut gaya selingkung yang ada di UNS Press, yaitu:

\section{Page Setup}

a. Ukuran margin atas $2,5 \mathrm{~cm}$; bawah $3 \mathrm{~cm}$; kiri $2,25 \mathrm{~cm}$; kanan 2,25 cm.

b. Ukuran kertas width $16 \mathrm{~cm}$ dan height $25 \mathrm{~cm}$. 
c. Layout, Header 1,5 cm (jarak judul buku di atas), Footer $2 \mathrm{~cm}$ (jarak halaman buku di bawah) dengan modus different odd and even.

2. Penggunaan huruf

a. Judul bab: Times New Roman 16 point, capital bold.

b. Judul sub bab: TNR 14 point, bold.

c. Judul sub-sub bab: TNR 11 point, bold.

d. Teks isi: TNR 11 point.

e. Keterangan gambar/tabel/diagram pada naskah: TNR 9 point, center, single spacing.

f. Header Arial 9 point bold.

g. Footer Arial 9 point bold.

h. Footnote TNR 9 point.

3. Penomoran dan pengaturan halaman

Format nomor: i, ii, iii, ... dan 1, 2, 3 tidak diperkenankan menggunakan bullet.

4. Format paragraf

5. Penulisan daftar pustaka

6. Urutan penulisan naskah

7. Urutan bagian buku

8. Penggunaan gambar pendukung

\section{Alur Penerimaan Naskah}

Kegiatan magang penyuntingan tahun 2019 lebih aplikatif dan banyak praktik langsung. Hal ini dikarenakan secara teori mengenai informasi detail tentang UNS Press telah didapatkan sebelum mulai melaksanakan magang. Pada saat pembukaan magang, pihak UNS Press juga memberikan informasi tambahan berkaitan dengan kegiatan yang ada di UNS Press. Salah satunya adalah alur penerimaan naskah yang ada di UNS Press. Berikut alur penerimaan naskah yang ada di UNS Press hingga menjadi naskah yang siap untuk dicetak, yaitu:

1. Penerimaan naskah

2. Pengecekan naskah

Naskah kemudian masuk ke bagian penerbitan, yang kemudian akan diseleksi kelayakan naskah terbit. 


\section{Editing}

a. Apabila naskah layak terbit, proses selanjutnya adalah editing manual. Penyuntingan ini dilakukan secara manual pada naskah hardfile, bila mana hal ini dimaksudkan agar lebih mudah, teliti, dan juga cermat dalam proses penyuntingan berikutnya.

b. Penyuntingan naskah secara manual selesai, langkah selanjutnya adalah melakukan editing softfile. Proses ini membutuhkan waktu yang cukup lama, karena di sini diperlukan kecermatan dan ketelitian yang tinggi.

c. Apabila proses editing softfile telah selesai, langkah selanjutnya adalah setting buku teks.

4. Layout

5. Katern

6. Pemberian Sampul Buku

7. Pemotongan

8. Blanding

9. Cek Ulang

10. Pengepakan

11. Penerbitan

\section{Kode Etik Penyuntingan Naskah}

Kode etik penyuntingan naskah merupakan pedoman bagi penyunting dalam menyunting naskah sesuai dengan kesepakatan bersama. Memahami kode etik penyuntingan naskah berarti penyunting harus tahu mana yang boleh dan tidak boleh dilakukan dalam penyuntingan naskah. Jika penyunting tidak memahami kode etik penyuntingan naskah menyebabkan terjadinya kemungkinan ia melakukan salah satu langkah atau salah sunting. Kode etik penyuntingan merupakan hal yang penting dan harus diperhatikan dalam proses penyutingan naskah. Berikut kode etik penyuntingan naskah yaitu:

1. Penyunting naskah mencari informasi mengenai data diri penulis naskah sebelum mulai disunting

Cara mencari informasi mengenai data diri penulis naskah dapat dilakukan melalui tiga cara. Pertama, menghubungi penulis secara lasngsung melalui temu muka, 
telepon, atau surat elektronik. Kedua, melalui editor penerbit bersangkutan yang pernah berhubungan dengan penulis. Ketiga, melalui penerbit lain yang pernah menerbitkan karya dari penulis tersebut. Hal ini dimksudkan untuk mengetahui gambaran tertentu mengenai penulis naskah.

2. Penyunting naskah bukanlah penulis naskah

Penyunting naskah bertugas membantu penulis atau pengarang. Namun, tanggung jawab materi atau isi naskah tetap ada pada penulis itu sendiri, bukan penyunting. Oleh karena itu, sebaiknya penyunting membatasi kedudukannya antara penyunting dengan penulis naskah.

3. Penyunting naskah wajib menghormati gaya selingkung penulis naskah, namun disesuaikan dengan gaya selingkung penerbit

Gaya selingkung penulis merupakan ciri hasil tulisan yang membedakan antara penulis satu dengan yang lain. Disisi lain, setiap penerbit juga memiliki gaya selingkung untuk hasil cetakan penerbit. Meskipun penyunting memiliki kewenangan mengubah naskah disana-sini (ejaan dsb), akan tetapi gaya selingkung penulis harus tetap ditampilkan dalam hasil tulisan.

4. Penyunting naskah wajib merahasiakan informasi yang terdapat dalam naskah yang disuntingnya

Sebelum naskah dipubilkasikan, informasi yang ada dalam naskah merupakan rahasia. Informasi tersebut hanya diketahui oleh penulis dan penyunting. Oleh karena itu, penyunting tidak boleh membocorkan informasi yang ada dalam naskah atau memberi tahu cuplikan isi naskah.

5. Penyunting naskah mengonsultasikan dengan penulis naskah jika ada perubahan Pada saat menyunting naskah, pihak penyunting harus mengonsultasikan dengan penulis naskah jika terdapat perubahan. Hal ini akan berakibat fatal apabila penyunting merasa 'sok tau' terhadap naskah orang lain. Hal ini bukan hanya merugikan penulis, namun juga akan merugikan penerbit.

6. Penyunting tidak boleh menghilangkan naskah yang akan, sedang, atau telah disunting

Penyunting tidak boleh menghilangkan naskah yang akan, sedang, atau telah disunting dengan alasan apapun. Penyunting naskah harus menjaga baik-baik naskah yang masih menjadi tanggung jawab penyunting. 


\section{Kepekaan Bahasa}

Pada aspek kepekaan bahasa, penyunting menggunakan daya sensori dan kepekaannya terhadap bahasa yang digunakan oleh penulis. Memiliki kepekaan bahasa penting dimiliki oleh penyunting. Hal ini karena penyunting berhubungan dengan kegiatan menyunting meliputi kepekaan ejaan bahasa Indonesia, tata bahasa Indonesia, dan kamus. Seorang penyunting naskah wajib dituntut untuk memiliki kepekaan bahasa. Penyunting harus memiliki kemampuan membedakan mana kata yang kasar dan kata yang dianggap halus; harus tahu mana kata yang perlu dihindari dan mana kata yang sebaiknya dipakai; dan harus tahu kapan kalimat atau kata tertentu digunakan atau dihindari. Oleh karena itu, seorang penyunting dituntut untuk memiliki kepekaan bahasa. Seorang penyunting perlu mengikuti tulisan pakar bahasa di media cetak untuk mendapatkan kepekaan bahasa seperti itu. Di samping itu, seorang penyunting naskah perlu mengikuti kolom bahasa yang ada disejumlah media cetak. Namun, hal yang lebih penting adalah mengikuti perkembangan bahasa Indonesia dari hari ke hari.

\section{PENUTUP}

Berdasarkan kegiatan magang penyuntingan di UNS Press tahun 2019 yang dilaksanakan pada tanggal 21 Januari 2019 sampai 1 Maret 2019, diperoleh hasil dan pembahasan mengenai gaya selingkung di UNS Press dan kode etik penyuntingan sebagai penopang eksistensi penulis Indonesia sebagai berikut: (1) UNS Press memiliki gaya selingkung sendiri yang terdiri dari delapan bagian, (2) alur penerimaan naskah di UNS Press terdapat sebelas langkah menerbitkan naskah dimulai dari penerimaan naskah hingga penerbitan naskah menjadi buku, (3) kode etik penyuntingan naskah terdiri dari enam poin yang menjadi pedoman bagi penyunting dalam menyunting naskah, dan (4) kepekaan bahasa berhubungan dengan kegiatan menyunting naskah meliputi kepekaan terhadap ejaan bahasa Indonesia, tata bahasa Indonesia, dan kamus. 


\section{DAFTAR PUSTAKA}

Arikunto, S. (2010). Penelitian Kualitatif. Jakarta: Bumi Aksara.

Ariningsih, N., Sumarwati, dan Kundharu Saddhono. (2012). Analisis Kesalahan Berbahasa Indonesia dalam Karangan Eksposisi Siswa Sekolah Menengah Atas. BASASTRA Jurnal Penelitian Bahasa, Sastra Indonesia dan Pengajarannya. 1 (1): April 2012.

Cahyaningrum, F., Andayani, dan Kundharu Saddhono. (2018). Improving Argumentation Writing Skill Through Think Pair Share Model Using Audiovisual Media for Students X-10 Grade of SMA Negeri Kebakkramat. Jurnal Pendidikan dan Kebudayaan. 3(1):44-55.

Eneste, P. (2014). Buku Pintar Penyuntingan Naskah Edisi Ketiga. Jakarta: Gramedia Pustaka Utama.

Irawati, L. (2016). Prosiding Seminar Nasional Hasil Penelitian Pola Retorika pada Sub Bagian Pembahasan dari Artikel Penelitian Berbahasa Inggris dan Berbahasa Indonesia yang Ditulis oleh Penulis Indonesia. FKIP, Universitas PGRI Madiun.

Kementerian Pendidikan dan Kebudayaan Indonesia. (2009). Kamus Besar Bahasa Indonesia. Jakarta: Balai Pustaka.

Mulyadi, Y. (2017). EBI + (Ejaan Bahasa Indonesia Plus). Bandung: Yrama Widya.

Profil UNS Press. Diperoleh tanggal 16 Juni 2019 dari https://uns.ac.id/id/fasilitaskampus/upt-uns-press

Ratna, N. K. (2012). Teori, Metode, dan Teknik Penelitian Sastra.Yogyakarta: Pustaka Pelajar.

Saddhono, K. dan St. Y. Slamet. (2012). Meningkatkan Keterampilan Berbahasa Indonesia (Teori dan Aplikasi). Bandung: Karya Putra Darwanti.

Sukardi, (2009). Metodologi Penelitian Pendidikan. Jakarta: Bumi Aksara.

Yahya, M., Andayani., dan Kundharu Saddhono. (2018). Hubungan Penguasaan Kosakata dengan Kesalahan Diksi dalam Kalimat Bahasa Indonesia Mahasiswa BIPA Level Akademik. Jurnal Kredo. 1 (2):70. 


\section{LAMPIRAN}

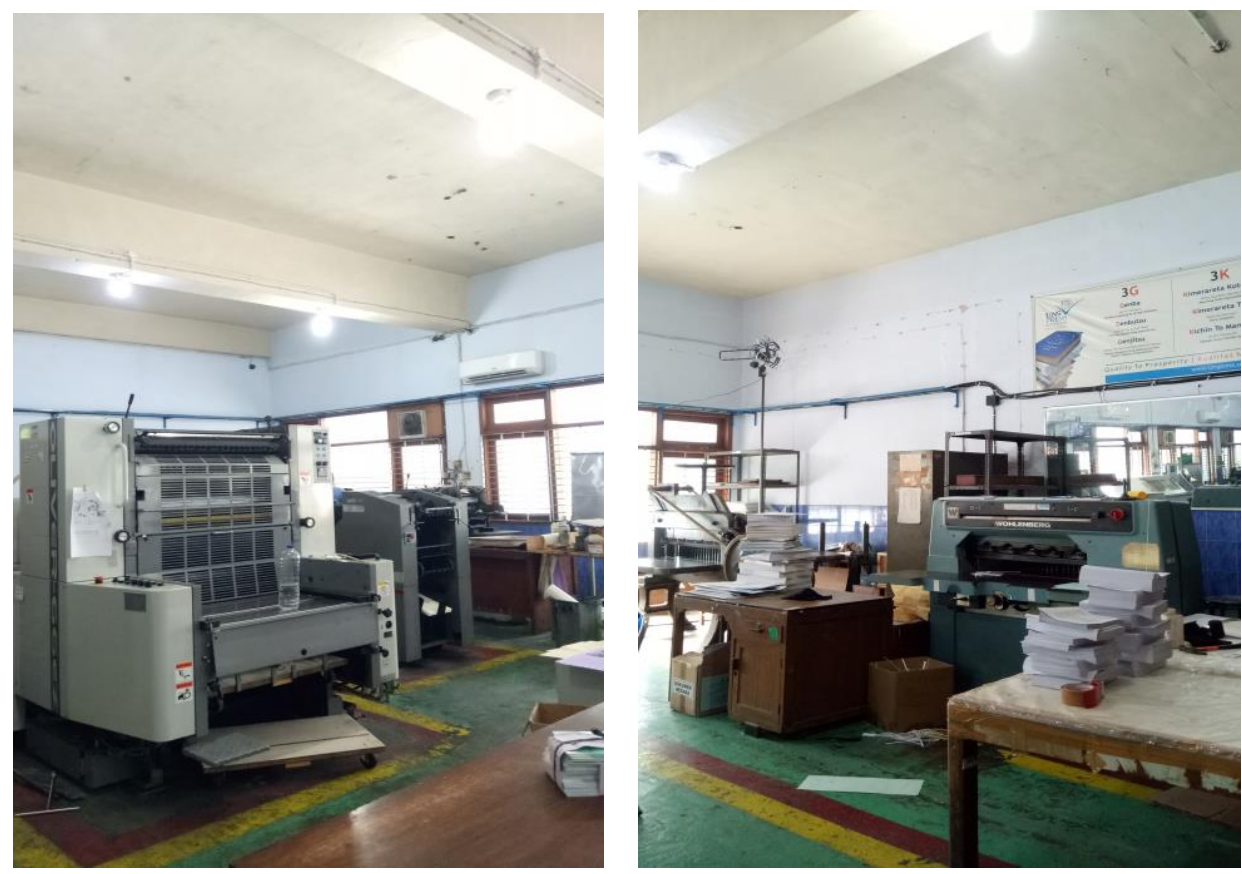

Mesin percetakan di UNS Press

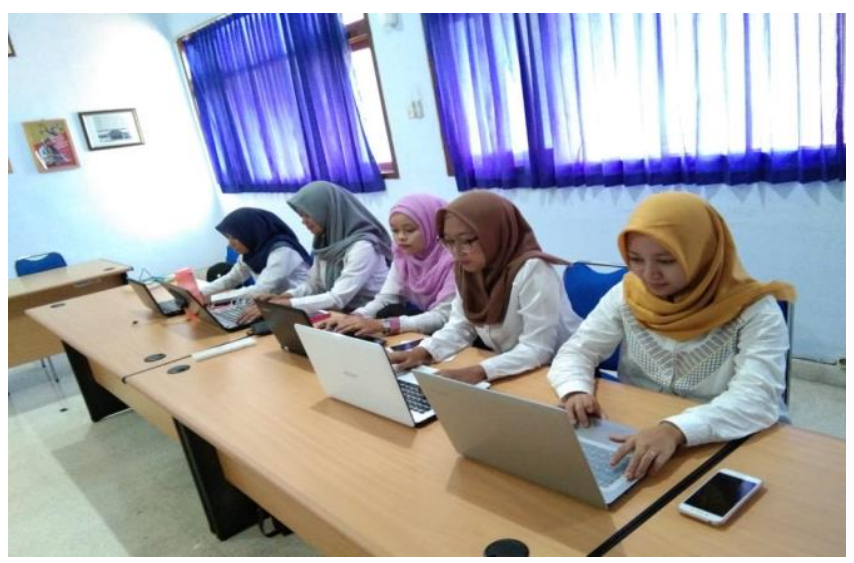

Kegiatan Menyunting

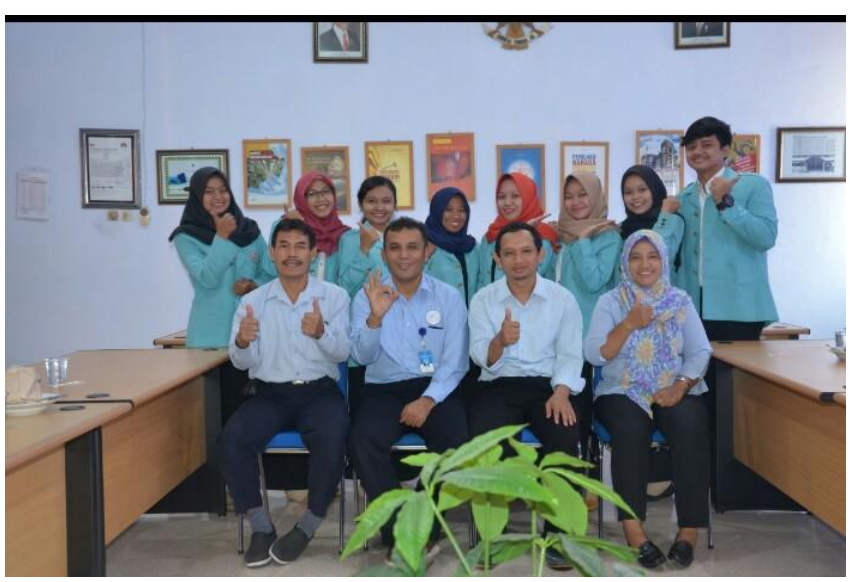

Kegiatan Pelepasan Magang Penyuntingan III 
BAB II

MODEL GEOGRAPHYCALLY WAEIGHTED REGRESSION (GWR)

Model Geographically Weighted Regression (GWR) adalah pengembangan dari model regresi dimana setiap parameter dihitung pada setiap lokasi pengamatan, sehingga setiap lokasi pengamatan mempunyai nilai parameter regresi yang berbedabeda. Model GWR merupakan pengembangan dari model regresi global dimana ide dasarnya diambil dari regresi non parametrik (Mei, 2006). Variabel respon $y$ dalam model GWR diprediksi dengan variabel prediktor yang masing-masing koefisien regresinya bergantung pada lokasi dimana data tersebut diamati. Model GWR dapat ditulis sebagai berikut (Fotheringham dkk, 2002):

$$
y_{i}=\beta_{0}\left(u_{i}, v_{i}\right)+\sum_{k=1}^{p} \beta_{k}\left(u_{i}, v_{i}\right) x_{i k}+\varepsilon_{i}
$$

dengan :

$y_{i} \quad$ : Nilai observasi variabel respon untuk lokasi ke- $i$

$\left(u_{i}, v_{i}\right) \quad$ : Menyatakan koordinat letak geografis (longitude, latitude) dari lokasi pengamatan ke- $i$

$\beta_{k}\left(u_{i}, v_{i}\right)$ : Koefisien regresi variabel prediktor ke- $k$ pada lokasi pengamatan ke- $i$

$x_{i k} \quad:$ Nilai observasi variabel prediktor ke- $k$ pada lokasi pengamatan ke- $i$

$\varepsilon_{i} \quad:$ Error pengamatan ke- $i$ yang diasumsikan identik, independen, dan berdistribusi normal dengan mean nol dan varian konstan $\sigma^{2}$

\subsection{Estimasi Parameter Model GWR}

Estimasi parameter model GWR dilakukan dengan metode Weighted Least Squares (WLS) yaitu dengan memberikan pembobot yang berbeda untuk setiap lokasi dimana data diamati. Pemberian bobot ini sesuai dengan Hukum I Tobler: "Everything is related to everything else, but near thing are more related than distant things/ Segala sesuatu saling berhubungan satu dengan yang lainnya, tetapi sesuatu yang dekat lebih mempunyai pengaruh daripada sesuatu yang jauh" (Miller, 2004). Oleh karena itu, model GWR diasumsikan bahwa daerah yang dekat dengan lokasi pengamatan ke- $i$ mempunyai pengaruh yang besar terhadap estimasi parameternya daripada daerah yang 
lebih jauh. Misalkan pembobot untuk setiap lokasi $\left(u_{i}, v_{i}\right)$ adalah $w_{j}\left(u_{i}, v_{i}\right), j=1,2, \ldots$, $n$ maka parameter pada lokasi pengamatan $\left(u_{i}, v_{i}\right)$ diestimasi dengan menambahkan unsur pembobot $w_{j}\left(u_{i}, v_{i}\right)$ pada persamaan (2.1) dan kemudian meminimumkan jumlah kuadrat residual berikut ini :

$$
\sum_{j=1}^{n} w_{j}\left(u_{i}, v_{i}\right) \varepsilon_{j}^{2}=\sum_{j=1}^{n} w_{j}\left(u_{i}, v_{i}\right)\left[y_{j}-\beta_{0}\left(u_{i}, v_{i}\right)-\sum_{k=1}^{p} \beta_{k}\left(u_{i}, v_{i}\right) x_{j k}\right]^{2}
$$

Atau dalam bentuk matriks jumlah kuadrat residualnya adalah:

$$
\begin{aligned}
\boldsymbol{\varepsilon}^{T} \mathbf{W}\left(u_{i}, v_{i}\right) \boldsymbol{\varepsilon}= & \mathbf{y}^{T} \mathbf{W}\left(u_{i}, v_{i}\right) \mathbf{y}-2 \boldsymbol{\beta}^{T}\left(u_{i}, v_{i}\right) \mathbf{X}^{T} \mathbf{W}\left(u_{i}, v_{i}\right) \mathbf{y} \\
& +\boldsymbol{\beta}^{T}\left(u_{i}, v_{i}\right) \mathbf{X}^{T} \mathbf{W}\left(u_{i}, v_{i}\right) \mathbf{X} \boldsymbol{\beta}\left(u_{i}, v_{i}\right)
\end{aligned}
$$

dengan:

$$
\boldsymbol{\beta}\left(u_{i}, v_{i}\right)=\left(\begin{array}{c}
\beta_{0}\left(u_{i}, v_{i}\right) \\
\beta_{1}\left(u_{i}, v_{i}\right) \\
\vdots \\
\beta_{p}\left(u_{i}, v_{i}\right)
\end{array}\right) \operatorname{dan} \mathbf{W}\left(u_{i}, v_{i}\right)=\operatorname{diag}\left(w_{1}\left(u_{i}, v_{i}\right), w_{2}\left(u_{i}, v_{i}\right), \cdots, w_{n}\left(u_{i}, v_{i}\right)\right) .
$$

Jika persamaan (2.2) diturunkan terhadap $\boldsymbol{\beta}^{T}\left(u_{i}, v_{i}\right)$ dan hasilnya disamakan dengan nol maka diperoleh estimator parameter model GWR:

$$
\begin{gathered}
\frac{\partial \boldsymbol{\varepsilon}^{T} \mathbf{W}\left(u_{i}, v_{i}\right) \boldsymbol{\varepsilon}}{\partial \boldsymbol{\beta}^{T}\left(u_{i}, v_{i}\right)}=0-2 \mathbf{X}^{T} \mathbf{W}\left(u_{i}, v_{i}\right) \mathbf{y}+2 \mathbf{X}^{T} \mathbf{W}\left(u_{i}, v_{i}\right) \mathbf{X} \boldsymbol{\beta}\left(u_{i}, v_{i}\right)=0 \\
-2 \mathbf{X}^{T} \mathbf{W}\left(u_{i}, v_{i}\right) \mathbf{y}+2 \mathbf{X}^{T} \mathbf{W}\left(u_{i}, v_{i}\right) \mathbf{X} \boldsymbol{\beta}\left(u_{i}, v_{i}\right)=0 \\
{\left[\mathbf{X}^{T} \mathbf{W}\left(u_{i}, v_{i}\right) \mathbf{X}\right]^{-1} \mathbf{X}^{T} \mathbf{W}\left(u_{i}, v_{i}\right) \mathbf{X} \boldsymbol{\beta}\left(u_{i}, v_{i}\right)=\left[\mathbf{X}^{T} \mathbf{W}\left(u_{i}, v_{i}\right) \mathbf{X}\right]^{-1} \mathbf{X}^{T} \mathbf{W}\left(u_{i}, v_{i}\right) \mathbf{y}} \\
\hat{\boldsymbol{\beta}}\left(u_{i}, v_{i}\right)=\left[\mathbf{X}^{T} \mathbf{W}\left(u_{i}, v_{i}\right) \mathbf{X}\right]^{-1} \mathbf{X}^{T} \mathbf{W}\left(u_{i}, v_{i}\right) \mathbf{y}
\end{gathered}
$$

Misalkan $\mathbf{x}_{i}^{T}=\left(1, x_{i 1}, x_{i 2}, \cdots, x_{i p}\right)$ adalah elemen baris ke- $i$ dari matriks $\mathbf{X}$. Maka nilai prediksi untuk y pada lokasi pengamatan $\left(u_{i}, v_{i}\right)$ dapat diperoleh dengan cara berikut:

$$
\hat{y}_{i}=\mathbf{x}_{i}^{T} \hat{\boldsymbol{\beta}}\left(u_{i}, v_{i}\right)=\mathbf{x}_{i}^{T}\left(\mathbf{X}^{T} \mathbf{W}\left(u_{i}, v_{i}\right) \mathbf{X}\right)^{-1} \mathbf{X}^{T} \mathbf{W}\left(u_{i}, v_{i}\right) \mathbf{y}
$$

Sehingga untuk seluruh pengamatan dapat dituliskan sebagai berikut:

$$
\begin{aligned}
& \hat{\mathbf{y}}=\left(\hat{y}_{1}, \hat{y}_{2}, \cdots, \hat{y}_{n}\right)^{T}=\mathbf{L y} \text { dan } \\
& \hat{\boldsymbol{\varepsilon}}=\left(\hat{\varepsilon}_{1}, \hat{\varepsilon}_{2}, \cdots, \hat{\varepsilon}_{n}\right)^{T}=(\mathbf{I}-\mathbf{L}) \mathbf{y}
\end{aligned}
$$


dengan $\mathbf{I}$ adalah matriks identitas berukuran nxn dan

$$
\mathbf{L}=\left(\begin{array}{c}
\mathbf{x}_{1}^{T}\left(\mathbf{X}^{T} \mathbf{W}\left(u_{1}, v_{1}\right) \mathbf{X}\right)^{-1} \mathbf{X}^{T} \mathbf{W}\left(u_{1}, v_{1}\right) \\
\mathbf{x}_{2}^{T}\left(\mathbf{X}^{T} \mathbf{W}\left(u_{2}, v_{2}\right) \mathbf{X}\right)^{-1} \mathbf{X}^{T} \mathbf{W}\left(u_{2}, v_{2}\right) \\
\vdots \\
\mathbf{x}_{n}^{T}\left(\mathbf{X}^{T} \mathbf{W}\left(u_{n}, v_{n}\right) \mathbf{X}\right)^{-1} \mathbf{X}^{T} \mathbf{W}\left(u_{n}, v_{n}\right)
\end{array}\right)
$$

Estimator $\hat{\boldsymbol{\beta}}\left(u_{i}, v_{i}\right)$ pada persamaan (2.3) merupakan estimator tak bias dan konsisten untuk $\boldsymbol{\beta}\left(u_{i}, v_{i}\right)$ (Nurdim, 2008).

\subsection{Pembobotan Model GWR}

Peran pembobot pada model GWR sangat penting karena nilai pembobot ini mewakili letak data observasi satu dengan lainnya. Skema pembobotan pada GWR dapat menggunakan beberapa metode yang berbeda. Ada beberapa literatur yang bisa digunakan untuk menentukan besarnya pembobot masing-masing lokasi yang berbeda pada model GWR, diantaranya dengan menggunakan fungsi kernel (kernel function).

Fungsi kernel digunakan untuk mengestimasi paramater dalam model GWR jika fungsi jarak $\left(w_{j}\right)$ adalah fungsi yang kontinu dan monoton turun (Chasco, Garcia, dan Vicens, 2007). Pembobot yang terbentuk menggunakan fungsi kernel ini adalah fungsi jarak Gaussian (Gaussian Distance Function), fungsi Exponential, fungsi Bisquare, dan fungsi kernel Tricube. Masing-masing fungsi pembobot dapat ditulis sebagai berikut :

1. Gaussian (Lesage, 2001):

$$
w_{j}\left(u_{i}, v_{i}\right)=\phi\left(d_{i j} / \sigma h\right)
$$

Dimana $\phi$ adalah densitas normal standar dan $\sigma$ menunjukkan simpangan baku dari vektor jarak $d_{i j}$.

2. Exponential (Lesage, 2001):

$$
w_{j}\left(u_{i}, v_{i}\right)=\sqrt{\exp \left(-\left(d_{i j} / h\right)^{2}\right)}
$$

3. Bisquare :

$$
w_{j}\left(u_{i}, v_{i}\right)= \begin{cases}\left(1-\left(d_{i j} / h\right)^{2}\right)^{2}, & \text { untuk } d_{i j} \leq h \\ 0, & \text { untuk } d_{i j}>h\end{cases}
$$


4. Tricube :

$$
w_{j}\left(u_{i}, v_{i}\right)= \begin{cases}\left(1-\left(d_{i j} / h\right)^{3}\right)^{3}, & \text { untuk } d_{i j} \leq h \\ 0, & \text { untuk } d_{i j}>h\end{cases}
$$

dengan $d_{i j}=\sqrt{\left(u_{i}-u_{j}\right)^{2}+\left(v_{i}-v_{j}\right)^{2}}$ adalah jarak eucliden antara lokasi $\left(u_{i}, v_{i}\right)$ ke lokasi $\left(u_{j}, v_{j}\right)$ dan $h$ adalah parameter non negatif yang diketahui dan biasanya disebut parameter penghalus (bandwidth).

Ada beberapa metode yang digunakan untuk memilih bandwidth optimum, salah satu diantaranya adalah metode Cross Validation (CV) yang secara matematis didefinisikan sebagai berikut:

$$
C V(h)=\sum_{i=1}^{n}\left(y_{i}-\hat{y}_{\neq i}(h)\right)^{2}
$$

dengan $\hat{y}_{\neq i}(h)$ adalah nilai penaksir $y_{i}$ dimana pengamatan di lokasi $\left(u_{i}, v_{i}\right)$ dihilangkan dari proses estimasi. Untuk mendapatkan nilai $h$ yang optimal maka diperoleh dari $h$ yang menghasilkan nilai CV yang minimum.

Metode Generalized Cross Validation (GCV) adalah

$$
\operatorname{GCV}(h)=\frac{n \sum_{i=1}^{n}\left(y_{i}-\hat{y}_{i}(h)\right)^{2}}{\left(n-v_{1}\right)^{2}}
$$

$\hat{y}_{i}(h)$ : Nilai penaksir $y_{i}$ (fitting value) dimana pengamatan di lokasi $\left(u_{i}, v_{i}\right)$ dimasukan dalam proses penaksiran

$v_{1} \quad$ : Jumlah penaksir yang efektif

\section{Pemilihan Model Terbaik}

Ada beberapa metode yang digunakan untuk memilih model terbaik salah satunya yaitu Akike Information Criterion (AIC) yang didefinisikan sebagai berikut :

$$
A I C=D(G)+2 K(G)
$$

dengan :

$$
D(G)=\sum_{i=1}^{n}\left(y_{i} \ln \hat{y}_{i}\left(\hat{\boldsymbol{\beta}}\left(u_{i}, v_{i}\right), G\right) / y_{i}+\left(y_{i}-\hat{y}_{i}\left(\hat{\boldsymbol{\beta}}\left(u_{i}, v_{i}\right), G\right)\right)\right)
$$


$D(G)$ merupakan nilai devians model dengan bandwidth $(G)$ dan $K$ merupakan jumlah parameter dalam model dengan bandwidth $(G)$. Model terbaik adalah model dengan nilai $A I C$ terkecil.

\subsection{Pengujian Hipotesis Model GWR}

Pengujian hipotesis pada model GWR terdiri dari pengujian kesesuaian model GWR dan pengujian parameter model. Pengujian kesesuaian model GWR (goodness of fit) dilakukan dengan hipotesis sebagai berikut :

$\mathrm{H}_{0}: \beta_{k}\left(u_{i}, v_{i}\right)=\beta_{k}$ untuk setiap $k=0,1,2, \cdots, p$, dan $i=1,2, \cdots, n$

(tidak ada perbedaan yang signifikan antara model regresi global dan GWR)

$\mathrm{H}_{1}$ : Paling sedikit ada satu $\beta_{k}\left(u_{i}, v_{i}\right) \neq \beta_{k}, k=0,1,2, \cdots, p$

(ada perbedaan yang signifikan antara model regresi global dan GWR).

Penentuan statistik uji berdasarkan pada Residual Sum of Square (RSS) yang diperoleh masing-masing dibawah $\mathrm{H}_{0}$ dan $\mathrm{H}_{1}$. Dibawah kondisi $\mathrm{H}_{0}$, dengan menggunakan metode OLS diperoleh nilai RSS berikut:

$$
\begin{aligned}
\operatorname{RSS}\left(\mathrm{H}_{0}\right) & =\hat{\boldsymbol{\varepsilon}}^{T} \hat{\boldsymbol{\varepsilon}}=(\mathbf{y}-\hat{\mathbf{y}})^{T}(\mathbf{y}-\hat{\mathbf{y}}) \\
& =\mathbf{y}^{T}(\mathbf{I}-\mathbf{H}) \mathbf{y}
\end{aligned}
$$

dengan $\mathbf{H}=\mathbf{X}\left(\mathbf{X}^{T} \mathbf{X}\right)^{-\mathbf{1}} \mathbf{X}^{T}$ yang bersifat idempotent.

Dibawah kondisi $\mathrm{H}_{1}$, koefisien regresi yang bervariasi secara spasial pada persamaan (2.4) ditentukan dengan metode GWR sehingga diperoleh nilai RSS berikut:

$$
\begin{aligned}
\operatorname{RSS}\left(\mathrm{H}_{1}\right) & =\hat{\boldsymbol{\varepsilon}}^{T} \hat{\boldsymbol{\varepsilon}}=(\mathbf{y}-\hat{\mathbf{y}})^{T}(\mathbf{y}-\hat{\mathbf{y}}) \\
& =\mathbf{y}^{T}(\mathbf{I}-\mathbf{L})^{T}(\mathbf{I}-\mathbf{L}) \mathbf{y}
\end{aligned}
$$

sehingga diperoleh statistik uji sebagai berikut (Leung dkk., 2000):

$$
F_{1}=\frac{R S S\left(\mathrm{H}_{1}\right) /\left(\frac{\delta_{1}^{2}}{\delta_{2}}\right)}{R S S\left(\mathrm{H}_{0}\right) /(n-p-1)}
$$

Dibawah $\mathrm{H}_{0}, \quad F_{1}$ akan mengikuti distribusi $\mathrm{F}$ dengan derajat bebas $d f_{1}=\left(\frac{\delta_{1}^{2}}{\delta_{2}}\right)$ dan $d f_{2}=(n-p-1)$. Jika diambil taraf signifikansi $\alpha$ maka tolak $\mathrm{H}_{0}$ jika $F_{1}<F_{1-\alpha, d f_{1}, d f_{2}}$. dengan: 


$$
\delta_{i}=\operatorname{tr}\left(\left[(\mathbf{I}-\mathbf{L})^{T}(\mathbf{I}-\mathbf{L})\right]^{i}\right), i=1,2
$$

Alternatif lain sebagai statistik uji adalah menggunakan selisih jumlah kuadrat residual dibawah $\mathrm{H}_{0}$ dan dibawah $\mathrm{H}_{1}$ (Leung dkk, 2000a), yaitu:

$$
\begin{aligned}
F_{2}= & \frac{\left(R S S\left(H_{0}\right)-R S S\left(H_{1}\right)\right) / \tau_{1}}{R S S\left(H_{1}\right) / \delta_{1}} \\
= & \frac{\mathbf{y}^{T}\left[(\mathbf{I}-\mathbf{H})-(\mathbf{I}-\mathbf{L})^{T}(\mathbf{I}-\mathbf{L})\right] \mathbf{y} / \tau_{1}}{\mathbf{y}^{T}(\mathbf{I}-\mathbf{L})^{T}(\mathbf{I}-\mathbf{L}) \mathbf{y} / \delta_{1}}
\end{aligned}
$$

Dibawah $\mathrm{H}_{0} \quad F_{2}$ akan mengikuti distribusi $\mathrm{F}$ dengan derajat bebas $d f_{1}=\frac{\tau_{1}^{2}}{\tau_{2}}$ dan $d f_{2}=\left(\frac{\delta_{1}^{2}}{\delta_{2}}\right)$. Jika diambil taraf signifikansi $\alpha$ maka tolak $\mathrm{H}_{0}$ jika $F_{2} \geq F_{\alpha, d f_{1}, d f_{2}}$.

dengan:

$$
\tau_{i}=\operatorname{tr}\left(\left[(\mathbf{I}-\mathbf{H})-(\mathbf{I}-\mathbf{L})^{T}(\mathbf{I}-\mathbf{L})\right]^{i}\right), i=1,2
$$

Jika disimpulkan bahwa model GWR berbeda nyata dengan model regresi global, maka langkah selanjutnya adalah melakukan uji parsial untuk mengetahui apakah ada perbedaan pengaruh yang signifikan dari variabel prediktor $x_{k}$ antara satu lokasi dengan lokasi lainnya (Mei, He dan Fang, 2004). Pengujian ini dapat dilakukan dengan hipotesis:

$\mathrm{H}_{0}: \beta_{k}\left(u_{1}, v_{1}\right)=\beta_{k}\left(u_{2}, v_{2}\right)=\cdots=\beta_{k}\left(u_{n}, v_{n}\right)$ untuk suatu $k(k=0,1,2, \cdots, p)$

(tidak ada perbedaan pengaruh yang signifikan dari variabel prediktor $x_{k}$ antara satu lokasi dengan lokasi lainnya)

$\mathrm{H}_{1}$ : Minimal ada satu $\beta_{k}\left(u_{i}, v_{i}\right)$, untuk $i=1,2, \ldots, n$ yang berbeda.

(ada perbedaan pengaruh yang signifikan dari variabel prediktor $x_{k}$ antara satu lokasi dengan lokasi lainnya)

Untuk melakukan pengujian di atas maka ditentukan terlebih dahulu varians $\hat{\beta}_{k}\left(u_{i}, v_{i}\right)(i=1,2, \ldots, n)$ yang dinotasikan dengan: 


$$
\begin{aligned}
V_{k}^{2} & =\frac{1}{n} \sum_{i=1}^{n}\left(\hat{\beta}_{k}\left(u_{i}, v_{i}\right)-\frac{1}{n} \sum_{i=1}^{n} \hat{\beta}_{k}\left(u_{i}, v_{i}\right)\right)^{2} \\
& =\frac{1}{n} \boldsymbol{\beta}_{k}^{T}\left[\mathbf{I}-\frac{1}{n} \mathbf{J}\right] \boldsymbol{\beta}_{k}
\end{aligned}
$$

dengan $\boldsymbol{\beta}_{k}\left(u_{i}, v_{i}\right)=\left(\begin{array}{c}\beta_{k}\left(u_{1}, v_{1}\right) \\ \beta_{k}\left(u_{2}, v_{2}\right) \\ \vdots \\ \beta_{k}\left(u_{n}, v_{n}\right)\end{array}\right)$.

Sedangkan statistik uji yang digunakan adalah:

$$
F_{3}=\frac{V_{k}^{2} / \operatorname{tr}\left(\frac{1}{n} \mathbf{B}_{k}^{T}\left[\mathbf{I}-\frac{1}{n} \mathbf{J}\right] \mathbf{B}_{k}\right)}{\operatorname{RSS}\left(\mathrm{H}_{1}\right) / \delta_{1}}
$$

dengan:

$$
\mathbf{B}_{k}=\left(\begin{array}{c}
\mathbf{e}_{k}^{T}\left[\mathbf{X}^{T} \mathbf{W}\left(u_{1}, v_{1}\right) \mathbf{X}\right]^{-1} \mathbf{X}^{T} \mathbf{W}\left(u_{1}, v_{1}\right) \\
\mathbf{e}_{k}^{T}\left[\mathbf{X}^{T} \mathbf{W}\left(u_{2}, v_{2}\right) \mathbf{X}\right]^{-1} \mathbf{X}^{T} \mathbf{W}\left(u_{2}, v_{2}\right) \\
\vdots \\
\mathbf{e}_{k}^{T}\left[\mathbf{X}^{T} \mathbf{W}\left(u_{n}, v_{n}\right) \mathbf{X}\right]^{-1} \mathbf{X}^{T} \mathbf{W}\left(u_{n}, v_{n}\right)
\end{array}\right),
$$

$\mathbf{e}_{k}$ adalah vektor kolom berukuran $(p+1)$ yang bernilai satu untuk elemen ke- $k$ dan nol untuk lainnya. Matriks L seperti pada persamaan (2.4) dan $\operatorname{RSS}\left(\mathrm{H}_{1}\right)$ seperti pada persamaan (2.5).

Dibawah $\mathrm{H}_{0}$, statistik uji $F_{3}$ akan berdistribusi $F$ dengan derajat bebas $d f_{1}=\left(\frac{\gamma_{1}^{2}}{\gamma_{2}}\right)$ dan $d f_{2}=\left(\frac{\delta_{1}^{2}}{\delta_{2}}\right)$ dengan $\gamma_{i}=\operatorname{tr}\left(\frac{1}{n} \mathbf{B}_{k}^{T}\left[\mathbf{I}-\frac{1}{n} \mathbf{J}\right] \mathbf{B}_{k}\right)^{i}, i=1,2$ dan $\delta_{i}$ seperti pada persamaan (2.6). Tolak $\mathrm{H}_{0}$ jika $F_{3} \geq F_{\alpha, d f_{1}, d f_{2}}$ (Leung dkk., 2000a).

Adapun pengujian signifikansi parameter model pada setiap lokasi dilakukan dengan menguji parameter secara parsial. Pengujian ini dilakukan untuk mengetahui parameter mana saja yang signifikan mempengaruhi variabel responnya. Bentuk hipotesisnya adalah sebagai berikut:

$$
\begin{aligned}
& \mathrm{H}_{0}: \beta_{k}\left(u_{i}, v_{i}\right)=0 \\
& \mathrm{H}_{1}: \beta_{k}\left(u_{i}, v_{i}\right) \neq 0 \text { dengan } k=1,2, \cdots, p
\end{aligned}
$$


Estimator parameter $\hat{\boldsymbol{\beta}}\left(u_{i}, v_{i}\right)$ akan mengikuti distribusi normal multivariat dengan rata-rata $\boldsymbol{\beta}\left(u_{i}, v_{i}\right)$ dan matrik matriks varian kovarian $\mathbf{C}_{i} \mathbf{C}_{i}^{T} \sigma^{2}$, dengan: $\mathbf{C}_{i}=\left(\mathbf{X}^{T} \mathbf{W}\left(u_{i}, v_{i}\right) \mathbf{X}\right)^{-1} \mathbf{X}^{T} \mathbf{W}\left(u_{i}, v_{i}\right)$, sehingga didapatkan:

$$
\frac{\hat{\beta}_{k}\left(u_{i}, v_{i}\right)-\beta_{k}\left(u_{i}, v_{i}\right)}{\sigma \sqrt{c_{k k}}} \sim \mathrm{N}(0,1)
$$

dengan $c_{k k}$ adalah elemen diagonal ke- $k$ dari matrik $\mathbf{C}_{i} \mathbf{C}_{i}^{T}$. Sehingga statistik uji yang digunakan adalah:

$$
T_{h i t}=\frac{\hat{\beta}_{k}\left(u_{i}, v_{i}\right)}{\hat{\sigma} \sqrt{c_{k k}}}
$$

